\title{
NOTICES OF BOOKS
}

Pali Text Societr. Points of Controversy or Subjects of Discourse, being a translation of the Kathā Vatthu from the Abhidhamma Pitaka. By Shwe Zas Aung, B.A., and Mrs. Rhys Davids, M.A. 1915 .

The title Points of Controversy, though less literal a translation than the sub-title of this work, is well chosen to indicate the nature of the text translated. The Kathā-Vatthu, classed as canonical, represents Buddhist orthodoxy at a later stage than the Pali Suttapitaka and under a different aspect. Even from the rest of the Abhidhammapitaka, to which it belongs, the KathaVatthu stands apart, not only by the presence of certain elements particular to itself, but by the label that orthodox opinion attached to it. It alone of the canonical Pali books has a traditional author and date. By generally received tradition the author is the learned and energetic Moggaliputta Tissa, and his work is a production associated with the Council of Patna held under Aśoka's patronage about B.c. 246. About that time, as is well known, the influence of the Buddhist school known as the Theravâdins was strong enough in India to bring about a historical Confession of the Faith and proclaim as orthodox the canon of scripture to which Ceylon and Further India have adhered down to the present day.

The particular feature of the Kathā-Vatthu just mentioned is the preservation in extremely brief form of the theses of certain schools, within the general Buddhist community, which had come to a more or less marked departure from orthodoxy. The text is thus 
a sort of manual of controversy for Buddhist teachers. It looks, on a first glance into the Pali, both dull and difficult. The dullness and difficulty have nevertheless yielded to work that may be compared to patient restoration of an old and curious picture-cleaned and restored the picture reveals a group of disputatious monks that interest the true student profoundly, little as he may expect it, in their cherished common tradition, their serious or fantastic differences, and the language and terms, most important to their doctrine, on which they cross-examined each other. As to the way in which the text assumed its present form there are some helpful observations in Mrs. Rhys Davids' Prefatory Notes. She considers that there is inner evidence in the KathaVatthu of slow growth by accretions. No work put together for a special occasion or to meet an entirely new need could conceivably have assumed the "patchwork quilt appearance" of the Kathā-Vatthu. Probably there was some sort of plan in it, but the series of debates "never exhaustive" on the views of various schools are not continued systematically. Then the disputes return, naturally enough, to single doctrines of importance, e.g. concerning the Buddha or arahants, several times. Mrs. Rhys Davids thinks it possible that "(1) each Kathā (or at times at two or more Kathās) was framed by or by order of the heads of the Sangha at the time when each seceding school newly systematized and taught this and that heresy or gave it occasional and special prominence, and that (2) such a new Kathä or sub-group of them was added by memorial or scriptural registration to the existing stock of Kathās".

'There are of course puzzles in these disputations for us who plunge into them centuries after they were recorded, and recorded, as we must remember, for those who were certainly familiar with many matters on which we have no information unless we can wring it from the 
commentaries. This we cannot always do. The commentator of the Kathā-Vatthu was not liberal with information as to matters of fact. In this case it was only the discussion of ideas and terms, as Mrs. Rhys Davids observes, that interested the many-sided Buddhaghosa; the translator must make the most of his threadbare details as to the external history of these early schools. We are left to speculate on most of the names adopted by eighteen distinct communities claiming to adhere to particular persons or doctrines or receiving their name from some particular locality. Their connexion, or the connexion of some of them, with the Council of Patna is re-stated in the commentator's introductory chapter, which serves as a prologue to the translated text. According to this the venerable Tissa arrayed 500 orthodox and 500 heterodox statements in a certain order and dealt with them all "to avert all bases of heresy that had arisen and that might in the future arise". With so much condensed into one canonical work we might expect a perfect example of the "Short Way with Dissenters"; but in regard to many questions the argument is turned various ways and the heterodox thinker pursued without haste from his position, cornered with logic and overborne by long quotations from the Suttapitaka. From this very brief description it will be seen how impossible it would be to give an intelligible translation of a work of this kind without a thorough knowledge of the Suttapitaka, the remaining books of the Abhidhamma, and the Commentary on the KathāVatthu. Mrs. Rhys Davids' record of work has but to be recalled, and when we rank this lately completed task with the others it is paying a high but only a just tribute to the volume before us. With respect to the translation Mrs. Rhys Davids speaks plainly: "We were not compiling a crib for learners of Pali," but her name and that of her collaborator are sufficient guarantee of the serious 
value of this version for the student of the original language. The expression quoted occurs with reference to a rather bold re-arrangement of the catechism or dialogues, so that the questions, answers, and repetitions could be condensed into one volume of translation. (Mr. Arnold C. Taylor's excellent edition makes two fullsized P.T.S. volumes.)

The re-arrangement, of course, calls for that close attention on the part of the student which the use of a crib is rather apt to undermine. It only means a little more exercise with the dictionary and a few salutary difficulties. On the other hand, the translators have spared no pains to throw a clear light on their text. They have added explanatory paragraphs from the Commentary and abundance of footnotes giving exact references to the canonical works quoted. The text is also supplemented by tables of contents so arranged as to show the grouping of subjects of controversy and the grouping of opinions under the names of such of the dissenting schools as here appear in the lists against the Theravadins. There are also Indexes and Supplementary Notes on certain important terms of the Abhidhamma. In the study of this terminology and in discussion of the logical method employed in the Kathā-Vatthu Mr. Shwe Zan Aung contributes generously of his learning and special knowledge as a Buddhist of Burma trained in the West. Critical treatment of a translation so full of difficulties could only be attempted by a critic able to claim competence in the matter at least approaching that of these experienced fellow-workers. Their critics in this branch of Pali studies will probably be just ready to begin when the present work and its predecessor, the Compendium of Philosophy, have become, like Buddhist Psychology, the classics on the subject.

M. H. B. 